\title{
Correction to: Security guards as victims of violence: using organisational support theory to understand how support for victims could have positive implications for the security industry
}

\section{Benjamin Koeppen ${ }^{1} \cdot$ Matt Hopkins $^{2}$}

Published online: 29 September 2020

(c) Springer Nature Limited 2020

\section{Correction to: Security Journal https://doi.org/10.1057/s41284-020-00257-z}

In the original publication of the article, the first author's given name is incorrectly published. The correct name should read as "Benjamin Koeppen".

The original article has been corrected.

Publisher's Note Springer Nature remains neutral with regard to jurisdictional claims in published maps and institutional affiliations.

The original article can be found online at https://doi.org/10.1057/s41284-020-00257-z.

\section{Matt Hopkins}

mh330@le.ac.uk

1 ING Bank, Theodor-Heuss-Allee 2, 60486 Frankfurt am Main, Germany

2 School of Criminology, University of Leicester, University Road, Leicester LE1 7RH, UK

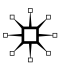

